\title{
Safe Place by Design: Urban Crime in Relation to Spatiality and Sociality
}

\author{
Hesam Kamalipour1,2, Mohsen Faizi', Gholamhossein Memarian1 \\ ${ }^{1}$ Department of Architecture, School of Architecture and Environmental Design, Iran University of Science \\ and Technology, Tehran, Iran \\ ${ }^{2}$ Department of Architecture, Saba Faculty of Art and Architecture, Shahid Bahonar University of Kerman, \\ Kerman, Iran \\ Email: hkamalipour@iust.ac.ir
}

Received 7 April 2014; revised 27 May 2014; accepted 11 June 2014

Copyright (C) 2014 by authors and Scientific Research Publishing Inc.

This work is licensed under the Creative Commons Attribution International License (CC BY). http://creativecommons.org/licenses/by/4.0/

(c) (7) Open Access

\section{Abstract}

Different conceptions of crime in design practice, sociology, environmental psychology, and criminology indicate an extensive articulation of crime in relation to the built environment and urban form in the city. Five decades of different studies on urban crime, crime prevention through environmental design, and fear of crime indicate an implicit and gradual movement from deterministic to possibilistic propositions in exploring the relationships between urban crime and environmental design both in theory and practice. Hence, the study firstly conducts a critical review on the issue of urban crime in relation to urban design, planning, and architecture disciplines. Categorizing different researches of urban crime in terms of their propositions and various dimensions of crime prevention through environmental design, the study proceeds to discuss the issue of crime in relation to spatiality and sociality in the city. Moreover, grounding the issue of safety in the context of place theory and avoiding deterministic and free-will approaches to urban crime, the study advocates for the necessity of mapping urban morphology, functional attributes, and spatial patterns in relation to socio-economic condition and demographic profiling. Thus, giving primacy to spatiality in relation to sociality and criticizing the absence of morphological mapping of urban crime, the study denotes the multi-scalar and multi-dimensional attributes of urban crime in relation to morphological, functional, perceptual, and social dimensions of a safe place by design.

\section{Keywords}

Urban Crime, CPTED, Urban Morphology, FOC, Safe Place, Spatiality and Sociality

\section{Introduction}

Considering the large body of knowledge and research on the issue of crime in relation to the built environment 
in terms of spatial structure, demographic status, urban morphology, sociocultural and economic condition, it is probable to conceive an evolutionary process in which different approaches and trends advocate for a comprehensive articulation of the complex relation between crime and the city. Despite the fact that crime is one of the critical problems of cities worldwide (Marzbali, Abdullah, Razak, \& Tilaki, 2012b), most of the previous studies have been conducted in sociology, criminology, and psychology in order to either explore the sociocultural and economic predictors of crime, whether in sociocultural context or individuals, or evaluate the proposed theories or propositions. However, although the studies have gradually extended the crime discourse over the hedge of narrow-minded determinism that was implicitly embedded with the early trends of environmental research on the issue of crime, they have relatively ignored or reduced the "complexity of the city problems" (Alexander, 1964; Jacobs, 1961; Portugali, 2011) into crime statistics while abstracting crime from its urban context. However, whilst planners and designers need to adopt theories and propositions in relation to spatiality and sociality domains in order to forecast the social outcomes of their spatial amendments in the built environment, the efficiency of these propositions remains ambiguous while societies are paying the price and the challenge is overwhelmingly critical when "design-level” theories are needed for interventions (Hillier, 2008). Thus, conducting an analytical review, the study advocates for the critical role of spatial structure and urban morphology in crime prevention through environmental design and fear of crime in the city.

Crime has been largely addressed in relation to sustainability in urban environments while unsustainable neighborhoods are mostly illustrated with a high crime rate, poverty, fear of crime, and homelessness (Cozens, 2008). Thus, the issue of safety has been considerably adopted as a part of sustainability (Black, 2004; Carmona, 2001). Furthermore, while environmental design envisions to meet human needs and desires (Lang, 1987; 2005), the issue of safety has been referred to as one of the basic human needs (Maslow, 1943). Since safety has a critical role in the practices of everyday life (Glasson \& Cozens, 2011) and policies of social welfare (Hummelsheim, Hirtenlehner, Jackson, \& Oberwittler, 2011), it has been considered as a human right equally as freedom in the human bill of rights (Body-Gendrot, 2000). Despite of the considerable body of knowledge on critical role of safety in the city, most of the planners, urban designers, and architects make decisions based on a partial or inadequate knowledge on attractors, generators, and patterns of crime that might lead to increasing the possibility of crime occurrence (P. J. Brantingham \& P. L. Brantingham, 1998). Thus, the issue of safety in the city and safe place in design-level interventions and decision-making process need to be addressed through multidisciplinary approaches including sociology, criminology, environmental psychology, planning, urban design, and architecture in order to cover different dimensions of the problem both in theory and practice.

\section{Urban Crime: Crime Prevention through Environmental Design and Fear of Crime in the City}

Crime has been referred to as a part of anomie that includes offender, victim, and situation (Felson, 1994). It has been noted that urban crime has considerable economic impacts on society rather than just psychological consequences (Glasson \& Cozens, 2011). Meanwhile, it has been largely argued that safety and crime are particularly linked to sustainability (Armitage \& Gamman, 2009; Cozens, 2002; Dewberry, 2003; Du Plessis, 1999) and place attachment (Kamalipour, Yeganeh, \& Alalhesabi, 2012; Scannell \& Gifford, 2010). In this way, crime prevention focuses on the efforts contributing to the aim of decreasing crime and fear of crime (Marzbali et al., 2012b; Nordqvist, Timpka, \& Lindqvist, 2009) in order to minimize possible problems of new designs based on previous practices (Clarke, 2009). In this way, crime prevention through environmental design (CPTED) denotes that an effective usage of built environment along with proper design interventions could improve the quality of life and decrease fear of crime (FOC) and crime occurrence (Crowe, 2000). Being categorized as a part of environmental criminology (Cozens, 2008) in which crime and victimization are explored in relation to place and ways of activity based on spatial factors (Bottoms \& Wiles, 1997), crime prevention through environmental design focuses on the relations between people and the environment. Thus, theoretical and practical articulations of the relations between crime and built environment are generally concerned with complex interrelations between sociality and spatiality discourse.

The main idea of crime prevention can be traced back to Jeffery (1971) as it is closely related to external physical environment and internal physical organism (Robinson, 1996). Crime prevention aims for identifying and changing kinds of environmental and social conditions in which particular opportunities provide the possibility of crime occurrence (Brantingham \& Faust, 1976). However, since the concept of environment in crime 
prevention through environmental design consists of both place and intruder, it could not be simply reduced to an external physicality (Robinson, 1996). Meanwhile, it has been argued that it is actually plausible to concentrate more on the external physical environments in comparison to people since the former is relatively more stable than the latter (Nasar \& Fisher, 1992; Robinson, 1996). In this way, considering the four approaches to environmental design in terms of relations between behavior and built environment as deterministic, opportunistic, possibilistic, and free-will propositions (Lang, 1987), it is possible to categorize different approaches to relations between crime and spatial variants of the built environment (Figure 1) based on their assumptions regarding the relations between human behavior and built environment.

While the process of decision-making takes place in-between the two ends of external environment of place and internal environment of intruder, deterministic approaches advocate for primacy of the external environment in comparison to free-will approaches in which the primacy is relatively given to the internal environment of intruder rather than the external environment in making decisions (Figure 1). Moreover, the possibi listic and probabilistic approaches are between the two ends of determinism and free-will approach. The primitive initiatives and trends in crime prevention through environmental design (Jacobs, 1961; Newman, 1972; Wood, 1961) relatively adopt a deterministic approach to the relations between human and environment in

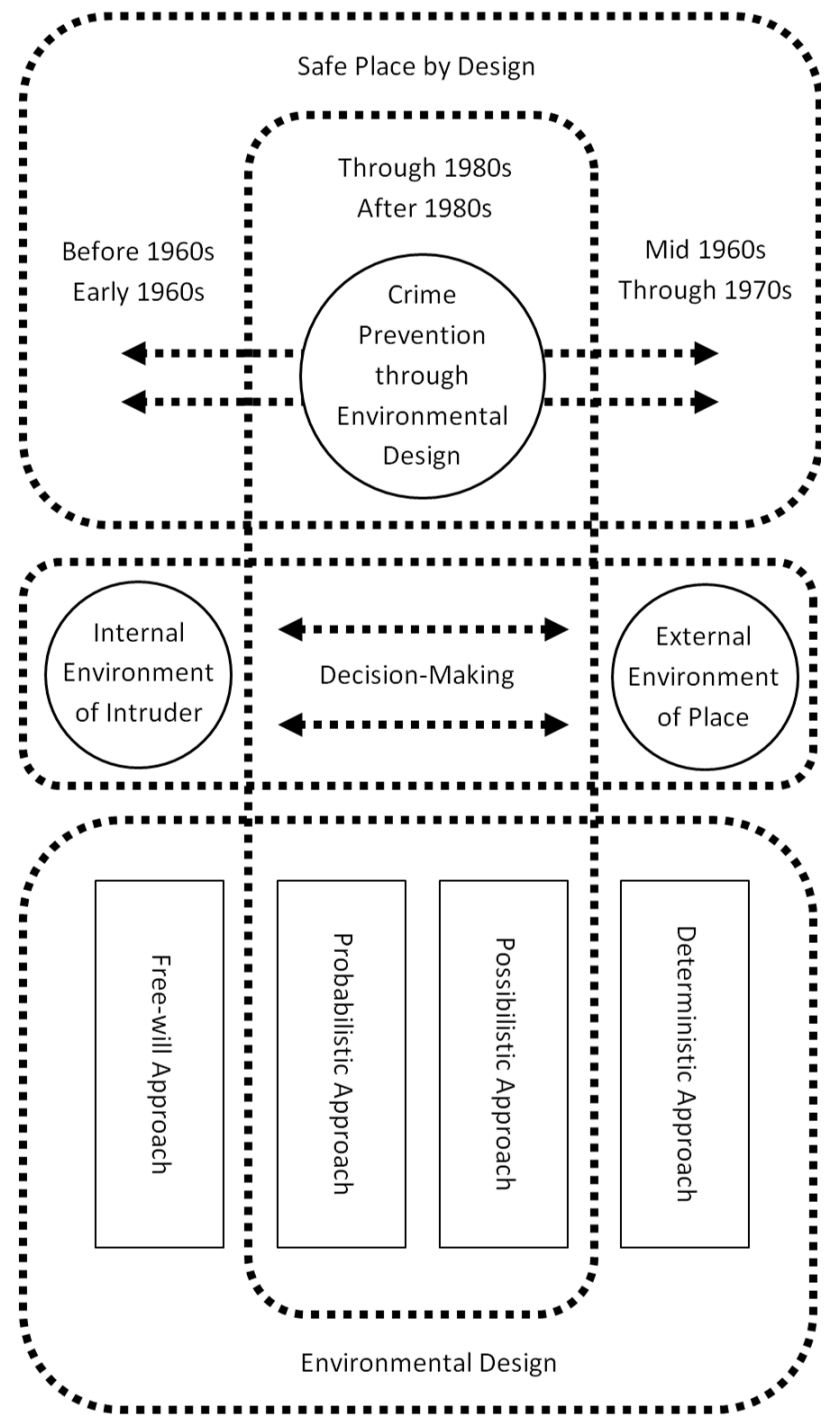

Figure 1. Different trends in crime prevention through environmental design and safe place in relation to Lang (1987) outlined approaches to environmental design. 
general and crime and built environment in particular. Further approaches to crime prevention through environmental design through 1980s and after 1980s as situational crime prevention (Clarke, 1980, 1992; Clarke \& Cornish, 1985), rational choice and opportunity (Cornish \& Clarke, 1986; Fattah, 1993), crime pattern theory (P. J. Brantingham \& P. L. Brantingham, 1981, 1984), and routine activity (Cohen \& Felson, 1979; Felson, 1995; Maxfield, 1987a; 1987b) adopt possibilistic or probabilistic approach to crime. In this way, there is a distinction between the first and second generations of CPTED in terms of addressing crime phenomenon as it is considerably related to either physical environment and spatial structure or socio-economic condition and cultural context.

While the approaches of the first-generation articulations of the relation between crime, spatiality, and sociality are relatively deterministic, the second-generation researches adopt possibilistic and probabilistic approaches to crime occurrence in urban environments in relation to socio-economic and demographic profiles rather than just considering the physical attributes of built environment (Table 1). Thus, whilst the criteria of the first generation have been categorized as territoriality, surveillance, access control, support activity, image and management, and target hardening, the dimensions of the second generation are risk assessment, socio-economic and demographic profiling, and community participation (Cozens, Saville, \& Hillier, 2005; Glasson \& Cozens, 2011). Although a considerable body of knowledge in crime prevention through environmental design has been devoted to the study of particular dimensions both in the first and second generations, but it should be noted that the outlined criteria have overlaps and loose boundaries (Ekblom, 2011). Thus, the proposed dimensions are not necessarily equal in terms of their impacts and factor loading. For example, territoriality in itself captures extensive conceptions and articulations in which all the other criteria, such as surveillance, access control, image and management, target hardening, risk assessment, and community participation are relatively involved. Moreover, the boundaries of the access control and target hardening criteria are defined in a way that they have an inevitable overlap in concept, meaning, representations, and spatial structures.

Furthermore, while the police statistics of crime is highly concerned with of quantity of the reported crime incidences, the fear of crime (FOC) has been largely neglected and undocumented (Cozens, 2008). Thus, fear of crime has become a particular field of study as a social problem in criminology (Lab, 2010; Lee, 2007). Fear of

Table 1. Comparing four models of crime prevention through environmental design from deterministic to possibilistic approaches based on Robinson (1996) argument on the process of CPTED development.

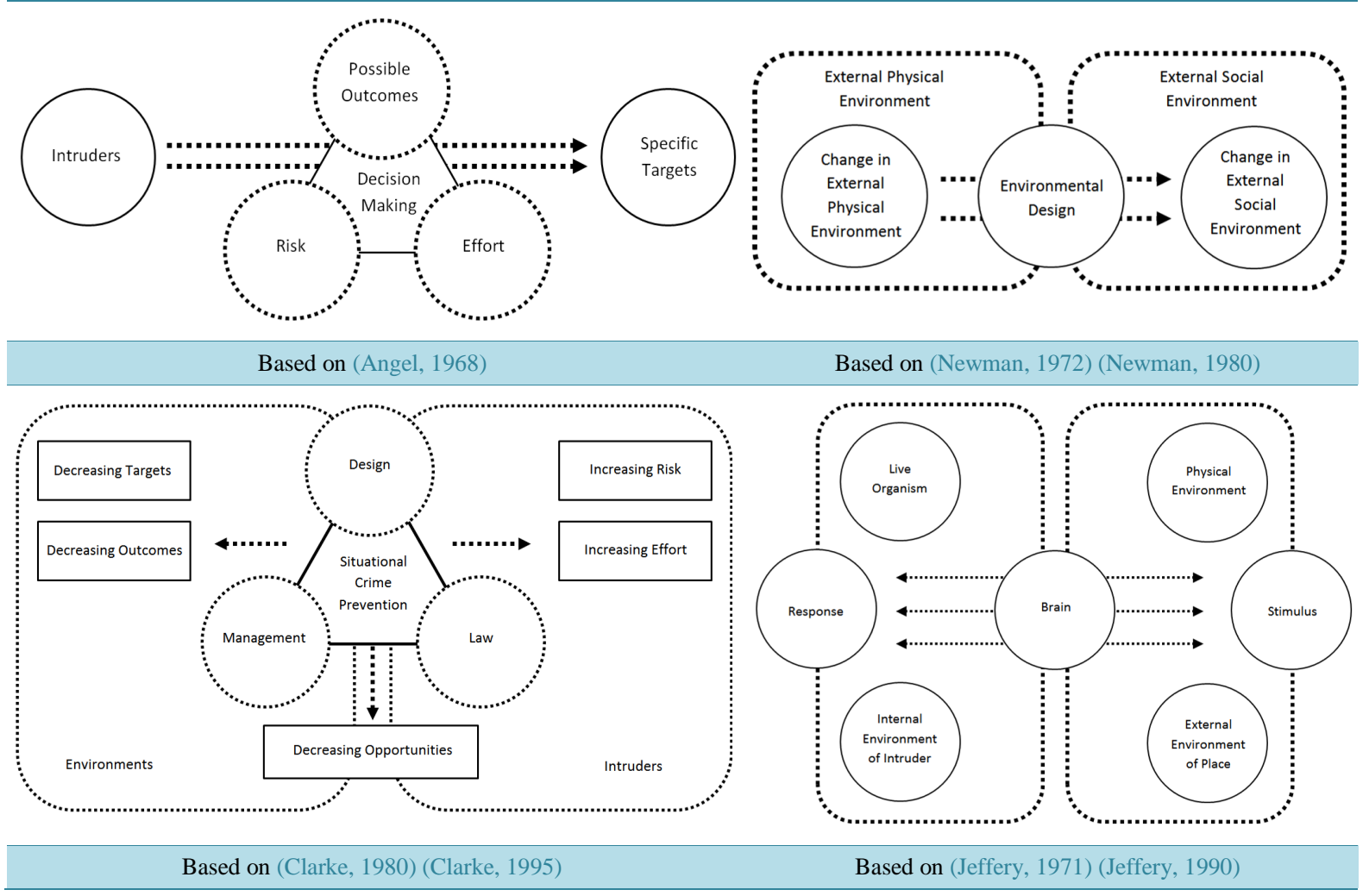


crime refers to the anxiety towards the occurrence of crime or the indicators that are related by individuals to crime (Ferraro, 1995). Besides, crime and fear of crime have been recognized as mediators between neighborhood features and the outcomes of wellbeing and mental health (Lorenc et al., 2012). However, a body of research on the relations between victimization and fear of crime indicates that there might not be necessarily a direct relationship between fear of crime and victimization (Marzbali, Abdullah, Razak, \& Tilaki, 2012a). Thus, fear of crime and perception of crime is different across various ages and time periods (Garofalo, 1979; Schneider \& Kitchen, 2002). Furthermore, mass media can also increase the fear of crime among individuals (Chadee \& Ditton, 2005; Colquhoun, 2004; Ditton, Chadee, Farrall, Gilchrist, \& Bannister, 2004). Meanwhile, most of the studies on fear of crime have implicitly or explicitly ignored and dismissed the complex relations between fear of crime and the built environment. Actually, fear of crime is closely related to the perceptual dimension of urban crime that needs to be analytically mapped in relation to spatial structure and patterns, functional attributes, and urban morphology.

Although social coherence can reduce the perceived risk (Wilcox et al., 2003; Rountree \& Land, 1996), but most of the conducted studies (Cohen et al., 2000; Perkins et al., 1992; Tseloni \& Zarafonitou, 2008) indicate that there is a relationship between incivility experiences, victimization, and fear of crime. Thus, fear of crime might decrease the usability of built environment for a part of society (Glasson \& Cozens, 2011) while it could be high in particular places that are not necessarily dangerous or distinguishable with a high level of crime incidences (P. J. Brantingham, P. L. Brantingham, \& Molumby, 1977; Vrij \& Winkel, 1991). In this way, fear of crime is one of the most considerable aspects of crime that is highly related to the perceptual dimension of crime. Hence, the perception of crime in urban environments is not necessarily in consistency with documented quantity of the reported crime occurrence.

Despite the necessity of design-level and evidence-based research on relations between urban crime and built environment, it is actually noteworthy to mention that most of the recent conducted studies on the relationships between fear of crime, sense of community, victimization, and crime prevention through environmental design (Abdullah, Marzbali, \& Tilaki, 2013; Abdullah, Marzbali, Woolley, Bahauddin, \& Maliki, 2013) are not necessarily accompanied with spatial analysis and mapping of urban morphology. Meanwhile, it has been noted that fear of crime is measurable in terms of worry of victimization, perceived risk, and disorder (Marzbali et al., 2012a). Thus, one of the common indicators among different conceptions of FOC is the worry of victimization that is relatively accompanied with anxiety towards physical and social environment.

\section{Safety by Design: Place Theory, Spatial Patterns, and Urban Morphology}

Being adopted as one of the most controversial and critical concepts in the studies of built environment, urban theory, and environmental psychology, place has been referred to as being closely related to the idea of being-in-the-world (Heidegger, 1962; Norberg-Schulz, 1980) and a combination of space and meaning (Tuan, 1977). Moreover, being criticized for reductionism (Casey, 1997) in relation to the practices of everyday life (Malpas, 2008), the concept of place has been referred to as a social construct in a mix of relations and activities (Massey, 1995). Hence, the practices of place-making and design-level interventions need to be closely based on a comprehensive understanding of spatiality in relation to sociality in the practices of everyday life in terms of the relationships between urban morphology, functional attributes, and social constructs of place. Thus, the issue of safety by design needs to be addressed within the context of place in relation to social constructs and practices of everyday life in the city.

While a considerable body of research on the issue of urban crime has been conducted within the domain of sociality in which the primacy of sociality has been taken for granted, urban design, planning, and architecture are likely to departure from spatiality for the study of relationships between crime and the city. Thus, spatial configuration and design patterns including urban morphology and functional attributes in relation to the possible social outcomes are the focus of a safe place by design. However, it should be noted that it is unrealistic to define a rigid boundary for either spatiality or sociality in the city (Figure 2). Thus, design practices of a safe place are in-between spatial structures and social constructs of place. While practices of urban design, planning, and architecture are concerned with design-level interventions, a poor understanding of urban morphology might lead to a poor design intervention (Marshall \& Çalişkan, 2011). In this way, design practices of a safe place give rise to the necessity of analyzing, mapping, and understanding of urban morphology in relation to urban crime and the city.

Whilst urban design is concerned with pattern creation, analysis, classification, interpretation, and definition, 


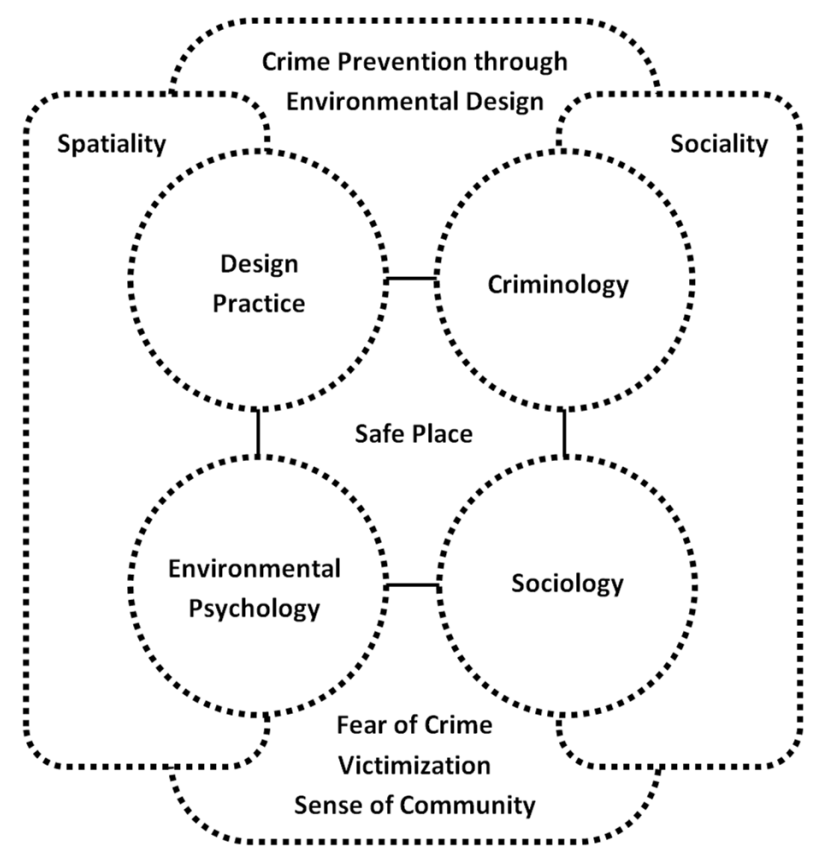

Figure 2. Safe place in relation to design practices, environmental psychology, criminology, and sociology within the complex relations between spatiality and sociality in the city.

urban morphology is about invention, pattern recognition, composition, and intervention (Marshall \& Çalişkan, 2011). Spatial patterns has been particularly addressed in the idea of "pattern language" (Alexander, Ishikawa, \& Silverstein, 1977) in relation to spatiality and urban crime (Kamalipour, Memarian, \& Faizi, 2014). Thus, a pattern addresses a problem and a solution in a context (Alexander, 1979). However, Rather than having a common ground, both urban design and morphology share the potentiality of a common language that is in fact morphological (Marshall \& Çalişkan, 2011). Thus, urban morphology concerns with concrete grounded outcome of socio-economic forces, intentions, ideas, and transformation of the city (Moudon, 1997). In this way, regardless of the critics of patterns and pattern language, the visual language, diagrammatic representation, and network-based connectivity of the patterns are relatively adoptable for presenting spatial patterns in relation to multi-scalar design-level interventions in the idea of safe place by design and understanding of urban morphology.

\section{A Safe Place: Urban Design in Relation to Spatiality and Sociality}

While most of the classic texts in urban design theory have been generally taken for granted and cited affirmatively, testing the core hypotheses and validation of propositions have been largely dismissed in further urban design studies (Marshall, 2012). In this way, due to the lack of empirically tested evidences, the efficiency of these beliefs remains vague and unsupported (Hillier, 2008). Crime prevention through environmental design and fear of crime are not exceptions because most of the related theories are not practically tested or supported in a scientific way with empirical evidences. However, considering the complex relations between spatiality and sociality in place research, there is a distinction between departure points from either spatiality or sociality in context of the city. Since both discourses of "society and space" and "urban sociology" are likely to put "society first" in which built environment is a spatial product of the underlying social processes, it is relatively improbable for them to acquire a degree of precision about the built environment for adopting testable design-level propositions (Hillier, 2008). In this way, since inconsistency and lack of robustness in "scientific grounding" can be considered as a possible reason for incoherent and highly criticized status of urban design theory (Marshall, 2012), the study advocates for evidence-based approach that departures from spatiality to explore the complex relations between crime and built environment. Moreover, adopting a holistic approach in relation to spatiality and sociality is crucial in the analysis of urban morphology for understanding the complex process of adaptation 
in terms of continuity and change in urban environments (Kamalipour, Arab, Soltani, Alavi, \& Mirzaei, 2013). Thus, crime needs to be explored in relation to morphological, functional, perceptual, and social dimensions of the city. In this way, a design-level approach to the idea of safe place by design is closely related to spatiality as a departure point for theoretical and empirical contributions in the study of urban crime.

With an assumption of "space reflects the society" in which particular spatial patterns are generated through certain underlying social processes and forces, it is relatively impossible to affirm that the spatial patterns are completely arbitrary (Hillier, 2008). Thus, the study gives primacy to spatiality in comparison to sociality for exploring the relations between crime and the city in order to advocate for the necessity of scientifically grounded theories and empirically tested propositions and evidences for design-level interventions in different scales. In this way, the spatial patterns and urban morphology should be explored in order to understand the possible social outcomes whether for intervention or research purposes. However, considering the spatiality-sociality relations in built environment, it should be noted that spatial patterns could not be taken for granted as arbitrary structures in the city (Hillier, 2008). In this way, space has a "social logic" that has been largely argued in "space syntax" theory (Hillier, 1996; Hillier \& Hanson, 1984). Moreover, the relationship between criminal activities and built environment is possibilistic rather than deterministic (Biddulph, 2007). Thus, both morphological and social attributes of a neighborhood are closely linked to the perception of inhabitants (Austin et al., 2002). In this way, methodology and research methods of design-level studies exploring the relations between urban space and crime include a combination of qualitative approaches and micro-scale analysis of spatial patterns (Hillier, 2004; Hillier \& Shu, 2000; Kamalipour, Memarian, Faizi, \& Mousavian, 2013). Besides, it has been argued that investments on design-level interventions, urban policies, and spatial patterns, which have been widely suggested in CPTED approach, are relatively more profitable and reasonable than increasing the quantity of police forces or conservatively policing and controlling the city (Crowe, 2000). Thus, while a comprehensive review of the related literature reveals both smooth and abrupt fluctuations between different approaches to crime prevention in sociology, criminology, environmental psychology, planning, architecture, and urban design, the study advocates for design-level researches through probabilistic or possibilistic approaches rather than determinism or free-will paradigm for exploring the complex relations between urban crime and spatial structures.

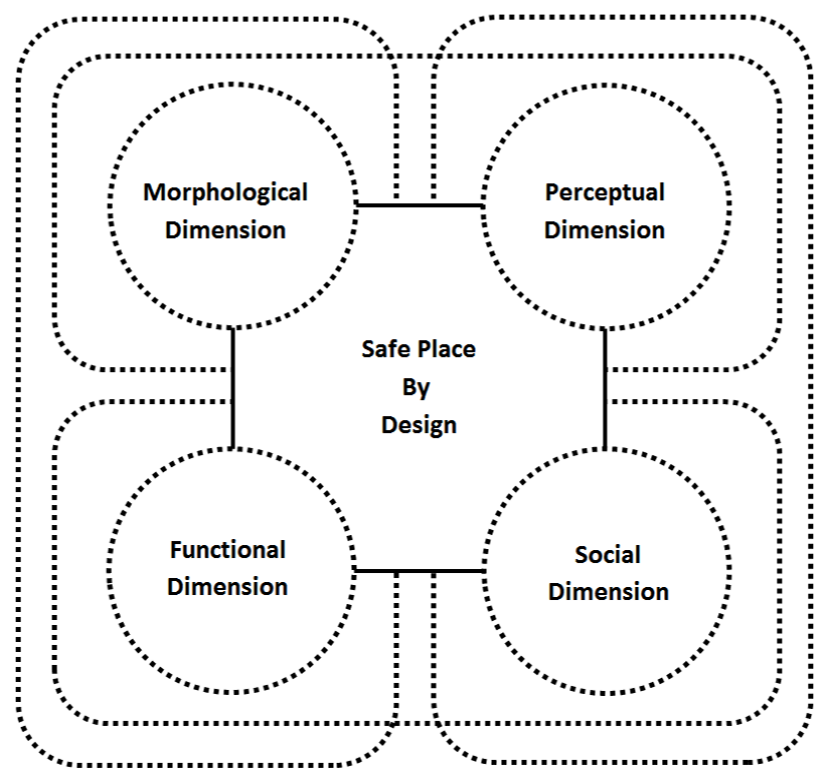

Figure 3. Interrelations between social, morphological, functional, and perceptual dimension of safe place by design.

Thus, the study accentuates the multi-scalar and multi-dimensional nature of crime prevention through environmental design as it is closely related to planning and design-level interventions in different scales and dimensions. In this way, various dimensions of crime prevention in both theory and practice can be categorized in morphological, social, functional, and perceptual dimensions (Figure 3). While the social and perceptual di- 
mensions of crime phenomenon have been widely addressed in criminology, environmental psychology, and sociology disciplines in terms of fear of crime, sense of community, people participation, demographic profiling, socio-economic attributes, risk, and victimization, the morphological and functional dimensions of urban crime have been relatively less explored comprehensively as a complex combination of urban forms and functions in relation to social and perceptual outcomes. Moreover, considering the complexity of the city as a combinational network of multi-scalar activities and emergence, the issue of urban crime needs to be explored in relation to various scales and dimensions of the city and urban environments.

\section{References}

Abdullah, A., Marzbali, M. H., \& Tilaki, M. J. M. (2013). Predicting the Influence of CPTED on Perceived Neighbourhood Cohesion: Considering Differences across Age. Journal of Environmental Psychology, 36, 54-64. http://dx.doi.org/10.1016/j.jenvp.2013.06.005

Abdullah, A., Marzbali, M. H., Woolley, H., Bahauddin, A., \& Maliki, N. (2013). Testing for Individual Factors for the Fear of Crime Using a Multiple Indicator-Multiple Cause Model. European Journal on Criminal Policy and Research, $20,1-22$. http://dx.doi.org/10.1007/s10610-013-9208-4

Alexander, C. (1964). A City Is Not a Tree. Architectural Forum, 122, 58-61.

Alexander, C. (1979). The Timeless Way of Building. New York: Oxford University Press.

Alexander, C., Ishikawa, S., \& Silverstein, M. (1977). A Pattern Language: Towns, Buildings, Construction. New York: Oxford University Press.

Angel, S. (1968). Discouraging Crime through City Planning. Berkeley, CA: University of California: Center for Planning and Development Research.

Armitage, R., \& Gamman, L. (2009). Sustainability via Security: A New Look. Built Environment, 35, 297-301. http://dx.doi.org/10.2148/benv.35.3.297

Austin, D. M., Furr, L. A., \& Spine, M. (2002). The Effects of Neighborhood Conditions on Perceptions of Safety. Journal of Criminal Justice, 30, 417-427. http://dx.doi.org/10.1016/S0047-2352(02)00148-4

Biddulph, M. (2007). Introduction to Residential Layout. Oxford; Burlington, MA: Butterworth-Heinemann.

Black, A. W. (2004). The Quest for Sustainable. Healthy Communities. Australian Journal of Environmental Education, 20, 33-44.

Body-Gendrot, S. (2000). The Social Control of Cities? A Comparative Perspective. Oxford; Malden, MA: Blackwell Publishers. http://dx.doi.org/10.1002/9780470712757

Bottoms, A. E., \& Wiles, P. (1997). Environmental Criminology. In M. Maguire, R. Moran, \& R. Reiner (Eds.), The Oxford handbook of Criminology (pp. 620-656). Oxford: Clarendon Press.

Brantingham, P. J., \& Brantingham, P. L. (1981). Environmental Criminology. Beverly Hills, CA: Sage Publications.

Brantingham, P. J., \& Brantingham, P. L. (1984). Patterns in Crime. New York: MacMillan.

Brantingham, P. J., \& Brantingham, P. L. (1998). Environmental Criminology: From Theory to Urban Planning Practice. Studies on Crime and Crime Prevention, 7, 31-60.

Brantingham, P. J., \& Faust, F. L. (1976). A Conceptual Model of Crime Prevention. Crime and Delinquency, 22, $284-295$. http://dx.doi.org/10.1177/001112877602200302

Brantingham, P. J., Brantingham, P. L., \& Molumby, T. (1977). Perceptions of Crime in a Dreadful Enclosure. The Ohio Journal of Science, 77, 256-261.

Carmona, M. (2001). Sustainable Urban Design: A Possible Agenda. London: Spon Press.

Casey, E. S. (1997). The Fate of Place. Berkeley, CA: University of California Press.

Chadee, D., \& Ditton, J. (2005). Fear of Crime and the Media: Assessing the Lack of Relationship. Crime Media Culture, 1, 322-332. http://dx.doi.org/10.1177/1741659005057644

Clarke, R. V. (1980). Situational Crime Prevention: Theory and Practice. Albany, NY: Harrow and Heston.

Clarke, R. V. (1995). Situational Crime Prevention. In M. Tonry, \& D. Farrington (Eds.), Building a Safer Society: Strategic Approaches to Crime Prevention (pp. 91-150). Chicago, IL: University of Chicago Press.

Clarke, R. V. (2009). Situational Crime Prevention: Theoretical Background and Current Practice. In M. D. Krohn, A. J. Lizotte, \& G. P. Hall, (Eds.), Handbook on Crime and Deviance (pp. 259-276). New York: Springer Science + Business Media.

Clarke, R. V., \& Cornish, D. B. (1985). Modeling Offenders’ Decisions: A Framework for Research and Policy. In M. Tonry, 
\& N. Morris (Eds.), Crime and Justice: An Annual Review of Research (pp. 147-185). Chicago, IL: University of Chicago Press.

Cohen, D., Spear, S., Scribner, R., Kissinger, P., Mason, K., \& Wildgen, J. (2000). “Broken Windows” and the Risk of Gonorrhea. American Journal of Public Health, 90, 230-236. http://dx.doi.org/10.2105/AJPH.90.2.230

Cohen, L. E., \& Felson, M. (1979). Social Change and Crime Rate Trends: A Routine Activity Approach. American Sociological Review, 44, 588-608. http://dx.doi.org/10.2307/2094589

Colquhoun, I. (2004). Design out Crime: Creating Safe and Sustainable Communities. Oxford; Burlington, MA: Architectural Press.

Cornish, D., \& Clarke, R. V. (1986). The Reasoning Criminal: Rational Choice Perspectives on Offending. Hague: SpringerVerlag.

Cozens, P. (2002). Sustainable Urban Development and Crime Prevention through Environmental Design for the British City. Towards an Effective Urban Environmentalism for the 21st Century. Cities, 19, 129-137. http://dx.doi.org/10.1016/S0264-2751(02)00008-2

Cozens, P. (2008). Crime Prevention through Environmental Design in Western Australia: Planning for Sustainable Urban Futures. International Journal of Sustainable Development and Planning, 3, 272-292. http://dx.doi.org/10.2495/SDP-V3-N3-272-292

Cozens, P., Saville, G., \& Hillier, D. (2005). Crime Prevention through Environmental Design (CPTED): A Review and Modern Bibliography. Property Management, 23, 328-356. http://dx.doi.org/10.1108/02637470510631483

Crowe, T. D. (2000). Crime Prevention through Environmental Design: Applications of Architectural Design and Space Management Concepts (2nd ed.). Oxford: Butterworth-Heinemann.

Dewberry, E. (2003). Designing out Crime: Insights from Ecodesign. Security Journal, 16, 51-62. http://dx.doi.org/10.1057/palgrave.sj.8340125

Ditton, J., Chadee, D., Farrall, S., Gilchrist, E., \& Bannister, J. (2004). From Imitation to Intimidation. British Journal of Criminology, 44, 595-610. http://dx.doi.org/10.1093/bjc/azh028

Du Plessis, C. (1999). The Links between Crime Prevention and Sustainable Development. Open House International, 24, 33-40.

Ekblom, P. (2011). Deconstructing CPTED... and Reconstructing It for Practice, Knowledge Management and Research. European Journal on Criminal Policy and Research, 17, 7-28. http://dx.doi.org/10.1007/s10610-010-9132-9

Fattah, E. A. (1993). The Rational Choice/Opportunity Perspectives as a Vehicle for Integrating Criminological and Victimological Theories. In R. V. Clarke, \& M. Felson (Eds.), Routine Activity and Rational Choice: Advances in Criminological Theory (pp. 225-258). New Brunswick, NJ: Transaction Publishers.

Felson, M. (1994). Crime and Everyday Life: Insights and Implications for Society. Thousand Oaks, CA: Pine Forge Press.

Felson, M. (1995). Those Who Discourage Crime. In J. E. Eck, \& D. Weisburd (Eds.), Crime and Place (pp. 53-66). Monsey, NY: Criminal Justice Press.

Ferraro, K. F. (1995). Fear of Crime: Interpreting Victimization Risk. New York: State University of New York Press.

Garofalo, J. (1979). Victimization and the Fear of Crime. Journal of Research in Crime and Delinquency, $16,80-97$. http://dx.doi.org/10.1177/002242787901600107

Glasson, J., \& Cozens, P. (2011). Making Communities Safer from Crime: An Undervalued Element in Impact Assessment. Environmental Impact Assessment Review, 31, 25-35. http://dx.doi.org/10.1016/j.eiar.2010.03.007

Heidegger, M. (1962). Being and Time (J. Macquarrie, \& E. Robinson, Trans.). New York: Harper \& Row.

Hillier, B. (1996). Space Is the Machine: A Configurational Theory of Architecture. Cambridge; New York: Cambridge University Press.

Hillier, B. (2004). Can Streets Be Made Safe? Urban Design International, 9, 31-45. http://dx.doi.org/10.1057/palgrave.udi.9000079

Hillier, B. (2008). Space and Spatiality: What the Built Environment Needs from Social Theory. Building Research \& Information, 36, 216-230. http://dx.doi.org/10.1080/09613210801928073

Hillier, B., \& Hanson, J. (1984). The Social Logic of Space. Cambridge; New York: Cambridge University Press. http://dx.doi.org/10.1017/CBO9780511597237

Hillier, B., \& Shu, S. (2000). Crime and Urban Layout: The Need for Evidence. In S. Ballintyne, K. Pease, \& V. McLaren (Eds.), Secure Foundations: Key Issues in Crime Prevention (pp. 224-248). London: Crime Reduction and Community Safety, Institute of Public Policy Research.

Hummelsheim, D., Hirtenlehner, H., Jackson, J., \& Oberwittler, D. (2011). Social Insecurities and Fear of Crime: A CrossNational Study on the Impact of Welfare State Policies on Crime-Related Anxieties. European Sociological Review, 27, 
327-345. http://dx.doi.org/10.1093/esr/jcq010

Jacobs, J. (1961). The Death and Life of Great American Cities. New York: Random House.

Jeffery, C. R. (1971). Crime Prevention through Environmental Design. Beverly Hills, CA: Sage Publications.

Jeffery, C. R. (1990). Criminology: An Interdisciplinary Approach. Englewood Cliffs, NJ: Prentice Hall.

Kamalipour, H., Arab, A. D., Soltani, S., Alavi, S. N., \& Mirzaei, E. (2013). Understanding Continuity and Change in the Persian Vernacular Settlements: A Comparative Syntactic Analysis of Urban Public Spaces in a Case Study. Current Urban Studies, 1, 130-138. http://dx.doi.org/10.4236/cus.2013.14014

Kamalipour, H., Memarian, G., \& Faizi, M. (2014). Urban Crime and Pattern Conceptions: Departuring from Spatiality. Open Journal of Social Sciences, 2, 441-450. http://dx.doi.org/10.4236/jss.2014.26051

Kamalipour, H., Memarian, G., Faizi, M., \& Mousavian, S. M. F. (2013). Evaluating CPTED Measures in Historical Urban Public Places: A Syntactic Analysis of a Case Study. Journal of Basic and Applied Scientific Research, 3, 795-805.

Kamalipour, H., Yeganeh, A. J., \& Alalhesabi, M. (2012). Predictors of Place Attachment in Urban Residential Environments: A Residential Complex Case Study. Procedia, Social and Behavioral Sciences, 35, 459-467. http://dx.doi.org/10.1016/j.sbspro.2012.02.111

Lab, S. P. (2010). Crime Prevention: Approaches, Practices, and Evaluations (7th ed.). New Providence, NJ: LexisNexis Matthew Bender.

Lang, J. T. (1987). Creating Architectural Theory: The Role of the Behavioral Sciences in Environmental Design. New York: Van Nostrand Reinhold Co.

Lang, J. T. (2005). Urban Design: A Typology of Procedures and Products. Oxford; Burlington, MA: Architectural Press.

Lee, M. (2007). Inventing Fear of Crime: Criminology and the Politics of Anxiety. Cullompton: Willan Publication.

Lorenc, T., Clayton, S., Neary, D., Whitehead, M., Petticrew, M., Thomson, H., Renton, A. et al. (2012). Crime, Fear of Crime, Environment, and Mental Health and Wellbeing: Mapping Review of Theories and Causal Pathways. Health \& Place, 18, 757-765. http://dx.doi.org/10.1016/j.healthplace.2012.04.001

Malpas, J. (2008). New Media, Cultural Heritage and the Sense of Place: Mapping the Conceptual Ground. International Journal of Heritage Studies, 14, 197-209. http://dx.doi.org/10.1080/13527250801953652

Marshall, S. (2012). Science, Pseudo-Science and Urban Design. URBAN DESIGN International, 17, 257-271. http://dx.doi.org/10.1057/udi.2012.22

Marshall, S., \& Çalişkan, O. (2011). A Joint Framework for Urban Morphology and Design. Built Environment, 37, $409-426$. http://dx.doi.org/10.2148/benv.37.4.409

Marzbali, M. H., Abdullah, A., Razak, N. A., \& Tilaki, M. J. M. (2012a). The Influence of Crime Prevention through Environmental Design on Victimisation and Fear of Crime. Journal of Environmental Psychology, 32, 79-88. http://dx.doi.org/10.1016/j.jenvp.2011.12.005

Marzbali, M. H., Abdullah, A., Razak, N. A., \& Tilaki, M. J. M. (2012b). Validating Crime Prevention through Environmental Design Construct through Checklist Using Structural Equation Modelling. International Journal of Law, Crime and Justice, 40, 82-99. http://dx.doi.org/10.1016/j.ijlcj.2011.08.005

Maslow, A. (1943). Motivation and Personality. New York: Harper.

Massey, D. B. (1995). The Conceptualization of Place. In D. B. Massey, \& P. Jess (Eds.), A Place in the World?: Places, Cultures and Globalization (pp. 45-85). Oxford; New York: Oxford University Press.

Maxfield, M. G. (1987a). Household Composition, Routine Activity, and Victimization: A Comparative Analysis. Journal of Quantitative Criminology, 3, 301-320. http://dx.doi.org/10.1007/BF01066833

Maxfield, M. G. (1987b). Lifestyle and Routine Activity Theories of Crime: Empirical Studies of Victimization, Delinquency, and Offender Decision-Making. Journal of Quantitative Criminology, 3, 275-282.

http://dx.doi.org/10.1007/BF01066831

Moudon, A. V. (1997). Urban Morphology as an Emerging Interdisciplinary Field. Urban Morphology, 1, 3-10.

Nasar, J. L., \& Fisher, B. (1992). Design for Vulnerability: Cues and Reactions to Fear of Crime. Sociological and Social Research, 76, 48-57.

Newman, O. (1972). Defensible Space; Crime Prevention through Urban Design. New York: Macmillan.

Newman, O. (1980). Community of Interest. Garden City, NY: Anchor Press/Doubleday.

Norberg-Schulz, C. (1980). Genius Loci: Towards a Phenomenology of Architecture. New York: Rizzoli.

Nordqvist, C., Timpka, T., \& Lindqvist, K. (2009). What Promotes Sustainability in Safe Community Programmes? BMC Health Services Research, 9, 4. http://dx.doi.org/10.1186/1472-6963-9-4 
Perkins, D., Meeks, J. W., \& Taylor, R. B. (1992). The Physical Environment of Street Blocks and Resident Perceptions of Crime and Disorder: Implications for Theory and Measurement. Journal of Environmental Psychology, 12, 21-34. http://dx.doi.org/10.1016/S0272-4944(05)80294-4

Portugali, J. (2011). Complexity, Cognition and the City. Berlin: Springer. http://dx.doi.org/10.1007/978-3-642-19451-1

Robinson, M. B. (1996). The Theoretical Development of CPTED: 25 Years of Responses to C. Ray Jeffery. In W. S. Laufer, \& F. Adler (Eds.), The Criminology of Criminal Law: Advances in Criminological Theory (pp. 427-462). New Brunswick: Transaction Publishers.

Rountree, P. W., \& Land, K. C. (1996). Burglary Victimization, Perceptions of Crime Risk, and Routine Activities: A Multilevel Analysis across Seattle Neighborhoods and Census Tracts. Journal of Research in Crime and Delinquency, 33, 147180. http://dx.doi.org/10.1177/0022427896033002001

Scannell, L., \& Gifford, R. (2010). Defining Place Attachment: A Tripartite Organizing Framework. Journal of Environmental Psychology, 30, 1-10. http://dx.doi.org/10.1016/j.jenvp.2009.09.006

Schneider, R. H., \& Kitchen, T. (2002). Planning For Crime Prevention: A Transatlantic Perspective. London: Routledge.

Tseloni, A., \& Zarafonitou, C. (2008). Fear of Crime and Victimization: A Multivariate Multilevel Analysis of Competing Measurements. European Journal of Criminology, 5, 387-409. http://dx.doi.org/10.1177/1477370808095123

Tuan, Y. F. (1977). Space and Place: The Perspective of Experience. Minneapolis, MN: University of Minnesota Press.

Vrij, A., \& Winkel, W. (1991). Characteristics of the Built Environment and Fear of Crime: A Research Note on Interventions in Unsafe Locations. Deviant Behavior, 12, 203-215. http://dx.doi.org/10.1080/01639625.1991.9967873

Wilcox, P., Quisenberry, N., \& Jones, S. (2003). The Built Environment and Community Crime Risk Interpretation. Journal of Research in Crime and Delinquency, 40, 322-345. http://dx.doi.org/10.1177/0022427803253801

Wood, E. (1961). Housing Design: A Social Theory. New York: Citizens’ Housing and Planning Council of New York. 
Scientific Research Publishing (SCIRP) is one of the largest Open Access journal publishers. It is currently publishing more than 200 open access, online, peer-reviewed journals covering a wide range of academic disciplines. SCIRP serves the worldwide academic communities and contributes to the progress and application of science with its publication.

Other selected journals from SCIRP are listed as below. Submit your manuscript to us via either submit@scirp.org or Online Submission Portal.
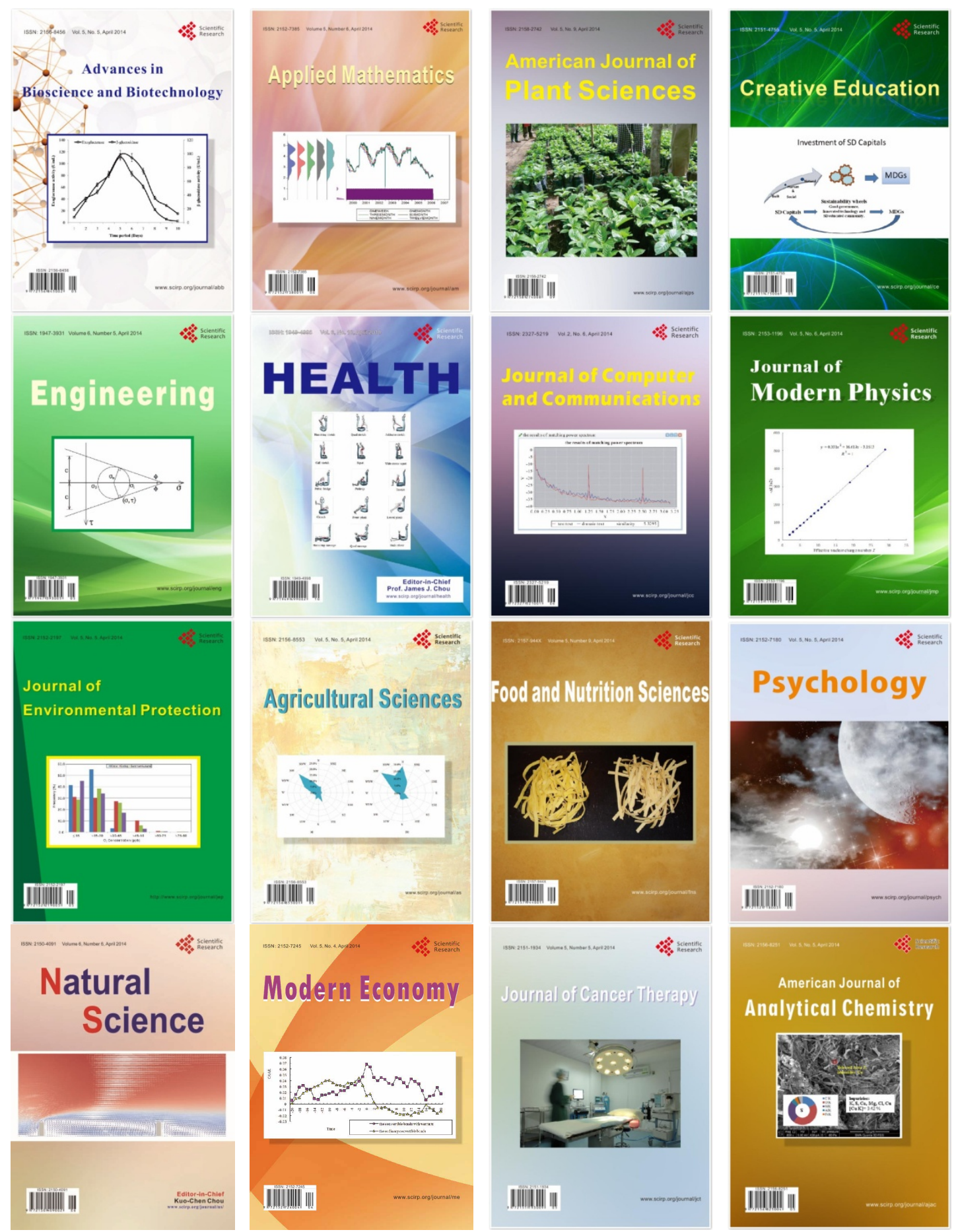